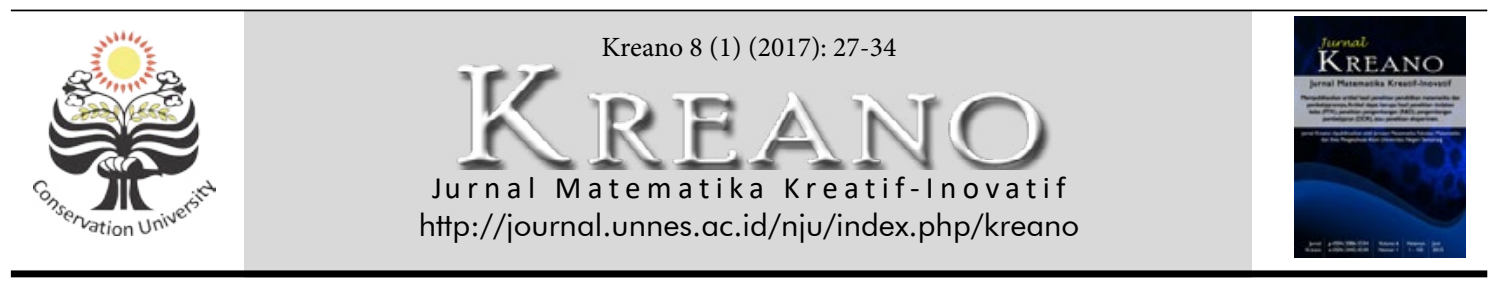

\title{
Strategi Pemecahan Masalah Matematika Siswa SMP Ditinjau dari Tingkat Berpikir Geometri Van Hiele
}

\author{
Diah Ayuningrum ${ }^{1}$ \\ 1 Prodi Pendidikan Matematika, Program Pascasarjana Universitas Negeri Surabaya, \\ Indonesia \\ Email: ayuningrum.diah568@gmail.com
}

DOI: http://dx.doi.org/10.15294/kreano.v8i2.6851

Received : August 2016; Accepted: April 2017; Published: June 2017

\begin{abstract}
Abstrak
Penelitian ini bertujuan untuk mendeskripsikan strategi pemecahan masalah matematika siswa SMP ditinjau dari tingkat berpikir geometri Van Hiele yaitu visualisasi, analisis dan deduksi informal. Penelitian ini merupakan penelitian kualitatif yang menghasilkan data deskriptif. Subjek penelitian ini terdiri dari tiga siswa kelas VIII-F SMPN 1 Waru, Sidoarjo. Penelitian ini dimulai dengan menentukan subjek penelitian dengan menggunakan tes tingkat berpikir geometri Van Hiele, kemudian dilanjutkan dengan pemberian tugas pemecahan masalah dan wawancara. Pengecekan keabsahan data menggunakan triangulasi waktu. Strategi pemecahan masalah siswa akan dianalisis berdasarkan tahapan pemecahan masalah Krulik dan Rudnick, yang terdiri dari (1) membaca dan berpikir, (2) mengeksplorasi dan merencanakan, (3) memilih suatu strategi, (4) menemukan jawaban, dan (5) meninjau dan mendiskusikan. Hasil penelitian menunjukkan bahwa 1) siswa visualisasi dalam memecahkan masalah matematika menggunakan strategi membuat gambar, berpikir logis, menulis persamaan atau kalimat terbuka, dan membuat daftar yang teratur, subjek visualisasi belum memahami bahwa persegi merupakan persegipanjang. 2) Siswa analisis memecahkan masalah matematika menggunakan strategi berpikir logis, menguji dan menerka serta membuat gambar, subjek analisis belum memahami bahwa persegi merupakan persegi panjang. 3) Siswa deduksi informal dalam memecahkan masalah matematika menggunakan strategi membuat gambar, berpikir logis, menulis persamaan atau kalimat terbuka serta menerka dan menguji, subjek deduksi informal telah memahami bahwa persegi merupakan persegipanjang.
\end{abstract}

\begin{abstract}
This study aimed to describe the mathematical problem-solving strategy of junior high school students based on Van Hiele levels of geometry thinking, namely visualization, analysis and informal deduction. This study was a qualitative research that produced descriptive data. Subjects of this study consisted of three students of class VIII-FSMPN 1 Waru, Sidoarjo. The study began by determining the subject of research by using Van Hiele's geometry test, and then given problem solving task and interviews. For checking the validity of the data used a triangulation of time. Student problem solving strategies will be analyzed based on the stages of Krulik and Rudnick's problem solving, which consists of (1) to read and think, (2) explore and plan, (3) selecting a strategy, (4) find the answers, and (5) review and discuss. The results showed that 1) the strategy of visualization student in solving mathematical problems was drew a picture, logical reasoning, wrote an equation or an open sentence, and made organized list, the visualization subject did not understood that a square was a rectangle. 2) The analysis student in solving mathematical problems was used logical reasoning strategies, guessed and checked, and drew a picture, the analysis subject did not understood that a square was a rectangle. 3) The strategy of informal deduction student in solving mathematical problem was drew a picture, logical reasoning, wrote an equation or an open sentence and guessed and checked, the subject of informal deductions had understood that a square was a rectangle.
\end{abstract}

Keywords: Problem Solving Strategy, Problem Solving, Van Hiele Geometry's Thinking Levels. 


\section{PENDAHULUAN}

Matematika memiliki peranan penting dalam berbagai aspek kehidupan. Salah satu cabang ilmu matematika adalah geometri. Geometri sangat dekat dengan kehidupan sehari-hari. Hakekatnya semua visualisasi yang ada di muka bumi ini adalah bentuk geometri. Pembelajaran geometri dapat mengembangkan kemampuan pemecahan masalah dan pemecahan masalah merupakan salah satu alasan utama untuk belajar matematika (Walle, 1990). Dengan belajar geometri siswa diharapkan dapat menjadi pemecah masalah yang baik (Abdussakir, 2012). Oleh karena itu, dengan belajar geometri siswa diharapkan dapat menganalisis masalah, memecahkan masalah dan membangun suatu hubungan antara matematika dan kehidupan sehari-hari.

Berdasarkan hasil study TIMMS tahun 2011, diperoleh fakta bahwa siswa Indonesia berada pada rangking amat rendah dalam hal teori, analisis dan pemecahan masalah. Selain itu, Wardhani \& Rumiati juga mengaji hasil studi TIMSS dan menjelaskan bahwa hanya $20 \%$ siswa Indonesia yang dapat menjawab dengan benar salah satu soal pemecahan masalah geometri mengenai konsep keliling persegi, persegipanjang dan jajargenjang. Hasil kajian tersebut mengindikasikan bahwa masih banyak siswa yang mengalami kesulitan dalam memecahkan masalah yang berkaitan dengan geometri (Wardhani \& Rumiati, 2011).

Kesulitan siswa dalam memecahkan masalah geometri disebabkan rendahnya kemampuan yang dimiliki dalam memecahkan masalah. Aydogdu menyatakan salah satu faktor penting yang mempengaruhi kemampuan seseorang dalam memecahkan masalah geometri adalah cara memilih dan menggunakan strategi pemecahan masalah (Branca, 1980).

Ada banyak strategi yang dapat digunakan untuk memecahkan masalah (Polya, 1973). Beberapa strategi pemecahan masalah yang sering digunakan dalam memecahkan masalah matematika yaitu membuat gambar (draw a picture), membuat tabel (make a table), membuat daftar yang teratur (make organized list), menerka dan menguji (guess and check), menyelesaikan masalah yang lebih sederhana (try a Simpler problem), men- cari pola/ generalisasi (looking for pattern), menulis persamaan/ kalimat terbuka (write an equation or open sentence), dan berpikir logis (logical reasoning) (Walle, 1990). Beberapa strategi dapat digunakan untuk menyelesaikan satu jenis masalah, namun satu strategi juga dapat digunakan untuk beberapa masalah. Strategi pemecahan masalah yang digunakan seseorang berbeda-beda bergantung terhadap pengalaman atau informasi yang dimiliki sebelumnya (Aydogdu, 2014).

Sehubungan dengan perbedaan penggunaan strategi dalam pemecahan masalah, maka guru sangat berperan penting dalam pembelajaran untuk memberikan pengalaman dan informasi kepada siswa dalam menerapkan strategi yang tepat guna memecahkan suatu permasalahan sehingga siswa memperoleh hasil belajar yang memuaskan dan tujuan pembelajaran yang ditetapkan tercapai. Salah satu ahli pendidikan yang juga memperhatikan tingkat kemampuan kognitif siswa adalah Van Hiele. Menurut teori Van Hiele, seseorang akan melalui lima tingkat perkembangan berpikir dalam belajar geometri yaitu tingkat o (visualisasi), tingkat 1 (analisis), tingkat 2 (deduksi informal), tingkat 3 (deduksi) dan tingkat 4 (rigor). Setiap tingkat dalam teori Van Hiele, menunjukkan karakteristik proses berpikir siswa dalam belajar geometri dan pemahamannya dalam materi geometri.

Hiele mengatakan bahwa kemajuan seseorang dari satu tingkatan ke tingkatan berikutnya lebih tergantung pada pengalaman belajar bukan pada kematangan atau usia (Siew, 2013). Beberapa penelitian yang telah dilakukan menunjukkan bahwa tingkat berpikir geometri siswa SMP berada pada tingkat visualisasi hingga deduksi informal. Penelitian yang dilakukan Burger \& Shaughnessy (1986) menyatakan bahwa tingkat berpikir siswa SMP dalam belajar geometri tertinggi pada tingkat 2 (deduksi informal) dan sebagian besar berada pada tingkat o (visualisasi). Oleh karena itu, peneliti tertarik untuk meneliti tentang strategi pemecahan masalah matematika siswa SMP ditinjau dari tingkat berpikir geometri Van Hiele.

\section{Pemecahan Masalah}

Masalah merupakan sesuatu yang tidak ter- 
lepas dari diri manusia. Adanya masalah mampu mendorong seseorang untuk mencari solusi guna memecahkan permasalahan yang dihadapi. Krulik \& Rudnik menyatakan masalah adalah suatu situasi yang dihadapi oleh seseorang atau kelompok yang memerlukan suatu pemecahan tetapi individu atau kelompok tersebut tidak memiliki cara yang langsung untuk menentukan solusinya (Krulik \& Rudnick, 1995). Sejalan dengan hal tersebut, Cooney juga mengemukakan suatu pertanyaan akan menjadi masalah jika pertanyaan itu menunjukkan adanya suatu tantangan (challenge) yang tidak dapat dipecahkan oleh suatu prosedur rutin yang telah diketahui siswa (Shadiq, 2004).

Branca (1980) menyatakan bahwa "Problem solving is the heart of mathematics" yang artinya jantungnya matematika adalah pemecahan masalah. Krulik dan Rudnik (1995) mendefinisikan "Problem solving is a process which an individualuses previously acquired knowledge, skills, and understanding tosatisfy the demands of an unfamiliar situation". Pemecahan masalah adalah suatu proses di mana individu menggunakan pengetahuan, ketrampilan dan pemahamannya untuk menemukan solusi dari suatu masalah.

Polya (1973) mengungkapkan terdapat empat langkah dalam memecahkan masalah yaitu: (a) Memahami masalah; (b) Merencanakan penyelesaian; (c) Melaksanakan Rencana; (d) Memeriksa kembali proses dan hasil. Krulik dan Rudnik (1988) juga menyatakan terdapat 5 langkah pemecahan masalah yaitu: (a) Membaca dan berpikir (read and think); (b) Mengeksplorasi dan merencanakan (Explore and plan); (c) Memilih suatu strategi (Select a strategy); (d) Menemukan suatu jawaban (find the answer); dan (e) Meninjau kembali dan mendiskusikan (reflect and extend). Dalam penelitian ini, langkah-langkah pemecahan masalah merujuk pada langkah pemecahan masalah Krulik \& Rudnick.

\section{Strategi Pemecahan Masalah}

Strategi pemecahan masalah adalah cara yang sering digunakan orang dan sering berhasil pada pemecahan masalah (Shadiq, 2004). Walle (1990) menyatakan bahwa strategi pemecahan masalah merupakan metode yang dapat diidentifikasi untuk mendekati sebuah tugas yang benar-benar independen dari topik tertentu.

Beberapa strategi yang digunakan siswa baik siswa kelas rendah maupun kelas tinggi, yaitu: (a) Menerka dan menguji (Guess and (heck). Strategi menebak yang cerdas ini didasarkan pada aspek-aspek yang relevan dengan permasalahan yang ada, ditambah dengan pengetahuan dari pengalaman yang dimiliki sebelumnya; (b) Membuat gambar, beraksi dan menggunakan model (Draw picture, Act It Out, Use Model). Strategi ini dapat digunakan untuk membantu memperjelas hubungan antara data yang diberikan dengan permasalahan yang dihadapi; (c) Mencari pola (Look for a pattern). Strategi ini berkaitan dengan pencarian keteraturan-keteraturan. Dengan keteraturan yang sudah didapatkan tersebut akan lebih memudahkan untuk menemukan penyelesaian masalah; (d) Membuat tabel atau diagram (Make a table or chart). Strategi membuat tabel bermanfaat ketika terdapat rangkaian bilangan pada permasalahan atau ketika solusi memungkinkan untuk ditemukan dalam bentuk tabel yang sistematis; (e) Membuat daftar yang teratur (Make an organized list). Membuat susunan daftar ini bermanfaat untuk menghitung semua kemungkinan jawaban dari suatu permasalahan; (f) Berpikir Logis (Logical Reasoning). Strategi ini berkaitan dengan penggunaan pemilihan notasi yang tepat, dapat memilih rumus yang tepat dan penalaran ataupun penarikan kesimpulan yang sah atau valid dari berbagai informasi atau data yang ada; (g) Mencoba masalah yang lebih mudah (Try a simple problem). Strategi ini berkaitan dengan penggunaan contoh-contoh khusus yang lebih mudah dan lebih sederhana, sehingga gambaran umum penyelesaian akan lebih mudah dianalisis dan lebih mudah ditemukan; dan (h) Menulis sebuah persamaan atau kalimat terbuka (Write an equation or open sentences). Persamaan atau pertidaksamaan yang dibaut akan mengarahkan pada kalimat terbuka dimana memuat variabel yang selanjutnya siswa akan menentukan nilai dari variabel tersebut sehingga diperoleh solusi yang benar (Walle, 1990; Yazgan, 2015). 


\section{Tingkat Berpikir Geometri Van Hiele}

Menurut teori Van Hiele, seseorang akan melalui lima tingkat perkembangan berpikir dalam belajar geometri. Setiap tingkat dalam teori Van Hiele, menunjukkan karakteristik proses berpikir siswa dalam belajar geometri dan pemahamannya dalam konteks geometri.

Lima tingkat berpikir geometri Van Hiele yaitu: (a) Tingkat o (Visualisasi). Pada level ini siswa hanya memperhatikan bangun secara visual saja tanpa mengetahui sifat-sifat bangun tersebut. Siswa pada tingkat ini elajar tetang bentuk suatu objek berdasarkan apa yang dia lihat"; (b) Tingkat 1 (Analisis). Pada tingkat ini siswa mulai menganalisis konsep geometri. Siswa sudah dapat mengenali dan menentukan karakteristik bangun dengan menganalisis sifat-sifat yang dimiliki bangun tersebut; (c) Tingkat 2 (Deduksi Informal). Pada tingkat ini siswa mulai dapat berpikir tentang sifat benda geometri tanpa kendala tertentu, mereka dapat melihat hubungan antar sifat-sifat dalam satu bangun; (d) Tingkat 3 (Deduksi). Pada tingkat ini berpikir deduksi siswa sudah mulai berkembang dan penalaran deduksi sebagai cara untuk membangun struktur geometri dalam sistem aksiomatik telah dipahami; dan (e) Tingkat 4 (Rigor). Siswa pada tingkat ini dapat memahami penggunaan bukti tak langsung dan bukti melalui kontra-positif, dan dapat memahami sistemsistem non-Euclidean (Burger \& Shaughnessy, 1986).

\section{METODE}

Penelitian Deskriptif Kualitatif ini menggunakan data kualitatif untuk mendeskripsikan secara jelas dan terperinci mengenai strategi pemecahan masalah matematika siswa ditinjau dari tingkat berpikir geometri Van Hiele. Subjek penelitian adalah 3 siswa SMPN 1 Waru Sidoarjo. Kegiatan pemilihan subjek dimulai dengan pemberian tes klasifikasi tingkat berpikir geometri Van Hiele sebagai pedoman untuk pengelompokan siswa. Tes klasifikasi tingkat berpikir geometri Van Hiele mengadaptasi dari Van Hiele's Geometry Test (VGHT) yang dikembangkan oleh Cognitive Development and Achievement in Secondary School Geometry dari Universitas Chicago (Usiskin, 1982).
Pemilihan subjek penelitian dilakukan dengan pemberian tes klasifikasi tingkat berikir geometri Van Hiele kepada 34 siswa. Dari hasil tes tersebut siswa dikelompokkan sesuai tingkat berpikir geometri dan dipilih masing masing satu orang siswa pada tiap tingkat berpikir geometri visulisasi, analisis dan deduksi informal. Setelah itu ketiga subjek diminta untuk mengerjakan tes pemecahan masalah dan dilakukan wawancara untuk memperoleh informasi yang lebih mendalam tentang strategi pemcahan masalah matematika siswa. Untuk memeriksa kekonsistenan data digunakan triangulasi waktu, sehingga tes pemecahan masalah dan wawancara dilakukan minimal sebanyak dua kali dalam waktu yang berbeda.

Selanjutnya, data strategi pemecahan masalah siswa akan dianalisis berdasarkan tahapan pemecahan masalah Krulik dan Rudnick, yang terdiri dari (1) membaca dan berpikir, (2) mengeksplorasi dan merencanakan, (3) memilih suatu strategi, (4) menemukan jawaban, dan (5) meninjau dan mendiskusikan. Berdasarkan analisis data tersebut, peneliti dapat mengambil kesimpulan tentang strategi pemecahan masalah maematika siswa SMP ditinjau dari tingkat berpikir geometri Van Hiele.

\section{HASIL}

Berdasarkan analisis data hasil penelitian maka diperoleh data tentang strategi pemecahan masalah matematika siswa sebagai berikut:

Siswa visualisasi menuliskan apa yang diketahui dan ditanyakan pada soal. Siswa visulisasi membuat sketsa dari soal yang diberikan untuk memberikan gambaran yang lebih jelas tentang masalah yang dihadapi. Hal tersebut terjadi karena siswa visualisasi memiliki kecenderungan belajar tentang objek geometri berdasarkan apa yang dia lihat. Pada tahap mengeksplorasi dan merencanakan, siswa visualiasi dapat menemukan hubungan antara informasi yang diketahui dan ditanyakan. Hal ini dikarenakan siswa visualisasi dapat menyelesaikan masalah yang tidak terlalu menekankan sifat-sifat pada suatu bangun secara umum (Fuys et al, 1988). Permasalahan di TPM yang diberikan tidak menekankan pada sifat sifat persegipanjang melainkan hanya 
pada ukuran yaitu luas dan kelililing dari persegipanjang. Oleh karena itu siswa visualisasi tersebut dapat dikatakan menggunakan strategi berpikir logis sesuai dengan yang dikemukakan Walle (1990) bahwa strategi ini (berpikir logis) berguna untuk menetapkan hubungan dari berbagai informasi yang diberikan.

Pada tahap memilih strategi, siswa memilih menggunakan strategi menulis persamaan atau kalimat terbuka dan membuat daftar yang teratur. Siswa visualisasi memilih menggunakan strategi menulis persamaan dan kalimat terbuka karena pada tingkat ini, siswa sudah dapat memahami ukuran suatu bentuk, ia dapat melakukan pengukuran suatu objek dengan baik meskipun tidak memahami sifat-sifat suatu objek secara keseluruhan. Siswa pada tingkat ini (visualisasi) dapat melakukan operasi pada pengukuran bangun datar, dan terkadang tentang sifat dari suatu bangun meskipun sifat-sifat tersebut tidak terlihat secara jelas.

Pada tahap menemukan jawaban, siswa melakukan langkah-langkah sesuai dengan yang ia rencanakan pada tahap sebelumnya. Siswa menggunakan strategi berpikir logis dimana ia menggunakan informasi yang terdapat dalam soal dengan menerapkan operasi perkalian dan pembagian. Ssiswa visualisasi dapat memecahkan permasalahan geometri dengan menyusun, mengukur, dan menghitung sesuai dengan apa yang diketahui pada permasalahan tersebut. Siswa juga menggunakan strategi menulis sebuah persamaan atau kalimat terbuka sehingga diperoleh penjumlahan dari panjang dan lebar. Siswa juga menulis semua kemungkinan, hal tersebut terjadi karena siswa visualisasi tidak dapat menganalisis suatu bangun berdasarkan sifat-sifatnya saja melainkan harus melihat gambar dari bangun tersebut sehingga siswa kurang dapat membayangkan berapa nilai untuk panjang dan lebar agar menghasilkan luas maksimal. Seperti yang diungkapkan oleh Burger \& Shaughnessy (1986) siswa tidak dapat menganalisis suatu bangun berdasarkan sifat-sifatnya dan hanya bergantung terhadap gambar. Siswa visualisasi belum memahami bahwa persegi merupakan persegipanjang sehingga ia salah dalam menentuka luas maksimal suatu bangun. Pada tahap me- ninjau kembali dan mendiskusi, siswa mengecek perhitungan, rumus yang digunakan serta kesesuaian jawaban dengan pertanyaan pada tiap langkah yang dilakukannya.

Siswa analisis mengungkap kembali masalah dengan bahasanya sendiri dan juga mengungkapkan hal yang diketahui dan ditanyakan pada soal dengan jelas sehingga tidak ada informasi yang tidak dipahami. Hal tersebut dapat terjadi karena siswa analisis sudah mampu membayangkan suatu objek berdasarkan sifat-sifat yang dimilikinya sehingga dengan informasi yang diberikan tanpa harus menggambar ia sudah dapat membayangkan bentuk bangun tersebut. Pada tahap mengekplorasi dan merencanakan, siswa menggunakan strategi berpikir logis. Siswa analisis menyelesaikan permasalahan geometri menggunakan sifat-sifat bangun atau dengan pendekatan penuh pemahaman. Oleh karena itu, bukan hal yang sulit untuk menemukan hubungan antara informasi yang diketahui dan ditanyakan serta informasi penting yang terdapat pada soal

Pada tahap memilih strategi, siswa analisis memilih menggunakan strategi menerka dan menguji. Walle (1990) mengungkapkan strategi menebak yang cerdas ini didasarkan pada aspek -aspek yang relevan dengan permasalahan yang ada, ditambah dengan pengetahuan dari pengalaman yang dimiliki sebelumnya. Siswa analisis menganalisis sifat-sifat dari bangun tersebut dan hubungan antar bagian, menentukan sifat-sifat dari kelas bangun secara empiris dan menggunakan sifat-sifat untuk memecahkan masalah. Oleh karena itu, dalam menggunakan strategi menerka dan menguji, siswa mengidentifikasi sifat-sifat persegipanjang kemudian memikirkan angka untuk nilai panjang dan lebar dan disesuaikan dengan keliling persegipanjang kemudian dipilih angka yang menghasilkan hasil kali yang paling besar guna menentukan luas maksimal.

Pada tahap menemukan jawaban, siswa menggunakan strategi berpikir logis dimana ia melakukan pemilihan notasi yang tepat, rumus yang tepat dan penalaran ataupun penarikan kesimpulan yang sah atau valid dari berbagai informasi-informasi yang diketahuinya hingga diperoleh solusi yang benar. Fuys 
(1988:60) menyatakan "student recall and uses appropriate vocabulary for components and relationship". Siswa mengingat dan menggunakan perbendaharaan yang sesuai untuk bagian-bagian dan hubungan-hubungan guna menyelesaikan masalah. Selanjutnya, siswa juga menggunakan strategi menerka dan menguji untuk menemukan panjang dan lebar sehingga diperoleh luas maksimal. Siswa menerka dan menguji sebanyak 3 kali hingga diperoleh luas maksimal. Menurut Fuys (1988) dalam hal ini, siswa membandingkan dua bangun atau lebih sesuai dengan hubungan diantara bagian-bagiannya.

Berdasarkan teori Van Hiele (dalam Crowley, 1987) bahwa tingkat berpikir geometri siswa bersifat rangkaian yang berurutan, maka siswa analisis sebelumnya sudah melalui tingkatan visualisasi. Oleh karena itu, dalam memecahkan permasalahan geometri kemampuan siswa yang dimiliki saat berada pada tingkat berpikir geometri visualisasi tidak hilang begitu saja, namun siswa juga dapat menerapkannya untuk menyelesaikan masalah. Dalam menyelesaikan permasalahan ini, siswa juga menggunakan strategi menggambar yaitu menggambar persegipanjang namun tidak menggunakan penggaris hanya sketsa saja. Subjek analisis salah menentukan luas maksimal karena subjek belum memahami bahwa persegi merupakan persegipanjang. Hal tersebut terjadi karena siswa pada tahap ini dapat mengenali dan menentukan karakteristik bangun dengan menganalisis sifat-sifat yang dimiliki bangun tersebut namun masih belum memahami hubungan antar bangun Pada tahap meninjau kembali dan mendiskusi siswa mengecek perhitungan, pada tiap langkah yang telah dilakukan serta kesesuaian jawaban dengan pertanyaan. Siswa juga mengungkap cara lain yaitu menggunakan rumus keliling, subjek mengungkapkan alasan tidak menggunakan cara itu karena jika menggunakan rumus lebih lama dan lebih rumit.

Siswa deduksi informal, pada tahap membaca dan berpikir ini juga mengungkapkan hal yang diketahui dan ditanyakan pada soal. Walle (1990) menyatakan pada tingkat ini siswa mulai dapat berpikir tentang sifat benda geometri tanpa kendala tertentu, mereka dapat melihat hubungan antar sifat-sifat dalam satu bangun. Ketrampilan menggambar siswa deduksi informal sudah baik, hal tersebut seperti yang diungkapkan Muhassanah (2014) bahwa "siswa deduksi informal mampu mengkonstruksi gambar sesuai dengan ciriciri dan sifat-sifat yang diberikan seperti dua garis yang saling sejajar, dua garis yang saling tegak lurus dan menentukan suatu titik". Oleh karena itu, siswa juga menggunakan strategi membuat gambar yaitu membuat sketsa untuk memperjelas masalah yang dihadapi.

Pada tahap mengekplorasi dan merencanakan, siswa menggunakan strategi berpikir logis. Fuys (1988) menyatakan pada tingkat ini, siswa mampu berpikir "jika ... maka" (tetapi bukan bukti formal) dan pada tingkat ini alasan yang bersifat logis bisa dikembangkan. Oleh karena itu, bukan hal yang sulit bagi siswa deduksi informal menggunakan strategi berpikir logis guna menemukan hubungan antara informasi yang diketahui dan ditanyakan serta beberapa informasi penting yang terdapat pada soal. Fuys et al (1988) mengungkapkan siswa deduksi informal mengidentifikasi dan menggunakan beberapa strategi atau memberi alasan logis untuk memecahkan masalah. Oleh karena itu, untuk memecahkan permasalahan siswa menggunakan beberapa strategi. Pada tahap memilih strategi, siswa memilih menggunakan strategi menulis persamaan atau kalimat terbuka dan strategi menerka dan menguji. Menurut Walle (1990) strategi menulis persamaan atau kalimat terbuka memungkinkan seseorang membentuk persamaan atau pertidaksamaan yang akan mengarahkan pada kalimat terbuka dimana memuat variabel yang selanjutnya siswa akan menentukan nilai dari variabel tersebut sehingga diperoleh solusi yang benar.

Siswa deduksi informal sudah mengenali sifat-sifat dari suatu bangun dan hubungan antar sifat-sifat tersebut serta memberikan alasannya dengan sangat baik. Oleh karena itu, bukan hal yang sulit bagi siswa deduksi informal untuk membuat persamaan dari rumus keliling persegipanjang sehingga diperoleh hasil penjumlahan dari panjang dan lebar persegipanjang kemudian siswa akan 
menebak dan menguji beberapa angka guna menentukan nilai panjang dan lebar yang memenuhi persamaan tersebut hingga diperoleh luas maksimal. Pada tahap menemukan jawaban, siswa menggunakan strategi berpikir logis dimana ia melakukan pemilihan notasi yang tepat, rumus yang tepat dan penalaran ataupun penarikan kesimpulan yang sah atau valid dari berbagai informasi-informasi yang diketahuinya hingga diperoleh solusi yang benar. Selanjutnya, siswa menggunakan strategi menulis persamaan atau kalimat terbuka. Siswa juga menggunakan strategi menerka dan menguji untuk menemukan panjang dan lebar sehingga diperoleh luas maksimal. Walle (1990) mengungkapkan strategi menebak yang cerdas ini didasarkan pada aspek -aspek yang relevan dengan permasalahan yang ada, ditambah dengan pengetahuan dari pengalaman yang dimiliki sebelumnya. Siswa menerka dan menguji sebanyak 3 sampai 5 kali hingga diperoleh luas maksimal. Fuys (1988) mengungkapkan siswa deduksi informal akan menggunakan lebih dari satu alasan/ penjelasan untuk membuktikan sesuatu dan menggeneralisasikan penjelasannya. Siswa mengungkap bagaimana cara menerka dan menguji yaitu memilih dua bilangan yang memiliki nilai yang besar karena akan menghasilkan hasil kali yang besar pula. Siswa dapat menentukan luas maksimal dengan benar, ia memahami bahwa persegi merupakan persegi panjang sehingga ia tidak kesulitan dalam menentukan luas maksimal suatu bangun. Hal tersebut dapat terjadi karena pada tingkat ini, siswa dapat menciptakan definisi yang bermakna dan memberi argumen informal untuk membenarkan penalaran mereka. Implikasi logis dan inklusi kelas, seperti persegi merupakan satu jenis dari persegi panjang bisa dipahami. Oleh karena itu bukan hal yang membingungkan atau sulit bagi siswa deduksi informal untuk menentukan luas maksimal dari suatu persegi panjang. Pada tahap meninjau kembali dan mendiskusi siswa menyatakan yakin dengan jawaban yang diberikan. Siswa mengecek perhitungan, rumus yang digunakan serta kesesuaian jawaban dengan pertanyaan.

\section{PENUTUP}

\section{Simpulan}

Berdasarkan pembahasan, dapat disimpulkan hal-hal sebagai berikut. (1) Siswa visualisasi memecahkan masalah dengan menggunakan strategi membuat gambar hal tersebut dilakukan untuk memberikan gambaran yang lebih jelas tentang permasalahan yang dihadapi. Strategi berpikir logis, menulis persamaan dan kalimat atau kalimat terbuka dan membuat daftar yang teratur digunakan untuk memecahkan masalah karena siswa visualisasi tidak mampu melakukan abstraksi terhadap permasalahan yang dihadapai. Siswa visualisasi belum memahami hubungan antar bangun yaitu tidak memahami bahwa persegi merupakan persegipanjang; dan (2) Siswa analisis mampu menggunakan sifat sifat dari suatu bangun sehingga ia menggunakan strategi berpikir logis dan strategi menerka dan menguji, serta menggunakan strategi menggambar pada akhir penyelesaian soal guna menguji jawaban yang diperoleh dari permasalahan tersebut. Namun terjadi kesalahan dalam penyelesaian karena siswa analisis belum memahami hubungan antar bangun yaitu tidak memahami bahwa persegi merupakan persegipanjang; serta (3) Siswa deduksi informal menggunakan strategi menggambar untuk memperoleh gambaran yang lebih jelas terhadap soal yang dihadapi. Siswa menggunakan strategi berpikir logis, menulis persamaan atau kalimat terbuka dan strategi menerka dan menguji. Siswa deduksi informal telah mampu melakukan abstraksi suatu bangun, memahami sifat-sifat suatu bangun, hingga hubungan antar bangun sehingga tidak mengalami kesulitan dalam menyelesaikan soal.

\section{Saran}

Berdasarkan hasil penelitian dan diskusi yang diajukan peneliti, peneliti memberikan saran sebagai berikut: (1) Hasil penelitian menunjukkan bahwa terdapat perbedaan penggunaan strategi pemecahan masalah namun siswa tidak dapat menunjukkan solusi lain untuk menyelesaikan masalah sehingga diharapkan guru dapat mengajarkan siswa berbagai penyelesaian masalah yang memung- 
kinkan dapat diselesaikan dengan beberapa strategi sehingga siswa dapat lebih meningkatkan kemampuan pemecahan masalahnya; (2) Dalam mengembangkan tugas pemecahan masalah hendaknya menggunakan soalsoal yang mencakup semua konsep matematika sehingga strategi pemecahan masalah matematika yang digunakan siswa dapat terlihat lebih detail dan jelas; (3) Kajian yang diamati dalam penelitian ini hanya terbatas pada tingkat berpikir geometri siswa. Oleh karena itu, diharapkan bagi peneliti selanjutnya yang akan melakukan penelitian tentang strategi pemecahan masalah siswa untuk memperluas kajian penelitian misalnya ditinjau dari kemampuan matematika, gender atau kecenderungan kepribadian siswa.

\section{DAFTAR PUSTAKA}

Abdussakir, A. (2012). Pembelajaran Geometri Sesuai Teori Van Hiele. MADRASAH, 2(1).

Aydoğdu, M. Z., \& Keşan, C. (2014). A Research On Geometry Problem Solving Strategies Used By Elementary Mathematics Teacher Candidates. Engineering Sciences \& Technologies/Nauki Inzynierskie iTechnologie, 4(1).

Branca, N. A. (1980). Problem Solving as a Goal, Process, and Basic Skill. Problem Solving in School Mathematics. Editor: Krulik, S. and Reys, R.E. Reston: National Council of Teachers of Mathematics.
Burger, W. F., \& Shaughnessy, J. M. (1986). Characterizing the van Hiele levels of development in geometry. Journal for research in mathematics education, 17(1), 31-48.

Fuys, D., Geddes, D., \& Tischler, R. (1988). The van Hiele model of thinking in geometry among adolescents. Journal for Research in Mathematics Education. Monograph, 3, i-196.

Krulik, S., \& Rudnick, J. A. (1995). The New Sourcebook for Teaching Reasoning and Problem Solving in Elementary School. Needham Heights: Allyn \& Bacon.

Polya, G. (1973). How to Solve it.NEW JERSEY: Princeton University Press.

Shadiq, F. (2004). Pemecahan Masalah, Penalaran dan Komunikasi. Yogyakarta: PPPG Matematika

Siew, N. M. (2013). Facilitating Students'geometric Thinking Through Van Hiele's Phase-Based Learning Using Tangram. Journal of Social Sciences, 9(3), 101-111.

Walle, J. A. (1990). Geometric Thinking and Geometric Concepts. In Elementary and Middle School Mathematics: Teaching Developmentally, 4th ed. Boston: Allyn and Bacon.

Wardhani, S., \& Rumiati. (2011). Instrumen Penilaian Hasil Belajar Matematika SMP: Belajar dari PISA dan TIMSS. Yogyakarta: PPPPTK

Usiskin, Z. (1982). Van Hiele levels of achievement in secondary school geometry. Final Report of the Cognitive Development and Achievement in Secondary School Geometry Project. Chicago: University of Chicago.

Yazgan, Y. (2015). Sixth graders and non-routine problems: Which strategies are decisive for success?. Journal of Elementary, 10(13), 1807-1816. 